Jurnal Akuntansi dan Investasi, Vol. 18 No. 2, Hlm: 209-221 Juli 2017

Artikel ini tersedia di website: http:/journal.umy.ac.id/index.php/ai

DOI: $10.18196 /$ jai.180284

\title{
Faktor-Faktor yang Berhubungan dengan Fraud Pengadaan Barang/Jasa di Lembaga Publik
}

\author{
Nashirotun Nisa Nurharjanti * \\ Prodi Akuntansi, Universitas Muhammadiyah Surakarta, Jl. A. Yani, Pabelan, Kartasura, \\ Surakarta 57162, Jawa Tengah, Indonesia
}

\begin{tabular}{l}
\hline A R T I C L E I N F O \\
\hline Article history: \\
received 24 Feb 2017 \\
revised 09 Mei 2017 \\
accepted 17 Jun 2017
\end{tabular}

Keywords:

Fraud Procurement;

Procurement Committee;

Supplier's Quality;

Procurement System;

Procurement Ethics;

Risk Assesment

\begin{abstract}
A B S T R A C T
The purpose of this study was to test whether the variable quality of the procurement committee of goods/services, quality of the patners goods/ services, systems and procedures for procurement of goods/services, ethical procurement of goods/services, environmental goods/services, and risk assessment have an influence on the procurement fraud goods/services in University. This study using survey method by distributing questionnaires in Asset Management and Maintenance Directorate of the University with the involvement of officials making commitments (PPK) totaling 3, the committee procurement of goods/services amounted to 22 people, and committee work proceeds amounted to 25 examiners. The gathered data was analyzed using multiple regressions in SPSS software. The result showed that the quality of procurement commite, supplier's quality, procurement system and procedure, and risk assesment had negatively influenced toward fraud in the procurement goods/services. Meanwhile, the procurement ethics and frameworks did not have influenced toward fraud in the procurement goods/services.
\end{abstract}

(C) 2017 JAI. All rights reserved

\section{PENDAHULUAN}

Kasus fraud yang marak terjadi saat ini dikarenakan adanya kepentingan pribadi atau sekelompok orang yang berada dalam organisasi ataupun yang berada diluar organisasi yang secara langsung dapat merugikan pihak lain. Kecurangan yang dilakukan tersebut dapat dikategorikan sebagai suatu perbuatan melawan hukum. Kasus fraud dewasa ini terjadi di berbagai bidang, termasuk dalam hal pengadaan barang/jasa di beberapa institusi perguruan tinggi (Komisi Pemberantasan Korupsi, 2013). Contoh nyatanya adalah adanya dugaan korupsi dalam proyek pengadaan alat laboratorium MIPA di salah satu Universitas Negeri di Jawa Timur. Selanjutnya, dari penyelidikan lebih lanjut oleh Komisi Pemberantasan Korupsi (KPK), ditemukan praktik korupsi pengadaan barang/jasa terjadi di lima perguruan tinggi negeri di Jawa dan Sumatera (detiknews, 2013). Latar belakang temuan tersebut ini lah yang menjadi alasan KPK untuk melakukan Kajian ulang atas regulasi dan praktik Pengadaan Barang dan Jasa di lembaga perguruan tinggi.

Mengacu pada Rahardja (2010), di sektor publik, indikasi dari kebocoran keuangan dapat dilihat dari banyaknya proyek yang tidak tepat waktu, tidak tepat sasaran, tidak tepat kualitas, tidak efisien, banyaknya alat yang dibeli tidak bisa dipakai, pengadaan barang/ jasa tidak didasarkan pada kebutuhan nyata, ambruknya bangunan gedung dan pendeknya umur konstruksi (masa pakainya hanya mencapai $30 \%-40 \%$ ), sejumlah persen komisi (fee) yang harus disetor oleh Kontraktor, Panitia Pengadaan dan PPK (Pimpro) kepada atasan, dengan dalih untuk belanja organisasi, perbedaan harga perkiraan sendiri (HPS) barang sejenis yang cukup mencolok antara satu instansi dengan instansi lain. Studi ini sendiri dilakukan sebagai suatu upaya untuk memberikan kontribusi literatur terkait upaya pencegahan serta penekanan tingginya angka tindak pidana korupsi pada Pengadaan Barang dan Jasa di lembaga publik.

Salah satu faktor yang mempengaruhi kebocoran keuangan pada proses pengadaan barang dan jasa adalah aspek etika dari panitia penyelenggara pengadaan. Razzaque dan Hwee (2002) menjelaskan bahwa perilaku fraud dapat dievaluasi dengan mengamati aspek etika seseorang yang dilihat dari sisi individual differences, interpersonal level factors, organizational level factors, 
serta dari persepsi dilema. Tang et al. (2003) menyatakan bahwa perilaku yang menyimpang atau tidak etis terdiri dari perilaku yang menyalahgunakan kedudukan/posisi (abuse position), kekuasaan (abuse power), sumber daya organisasi (abuse resources), serta tidak berbuat apa-apa (no action).

Perilaku tidak etis dan kecenderungan terjadinya manipulasi akuntansi dapat diturunkan dengan meningkatkan keefektifan pengendalian intern, ketaatan aturan akuntansi, moralitas manajemen serta menghilangkan asimetri informasi (Wilopo, 2006). Menurut Jatiningtyas dan Endang (2011) aspek yang dapat mempengaruhi proses pengadaan barang/jasa seperti aspek etika, pengendalian internal dan transparansi. Dari penjelasan tersebut, maka peneliti ingin mengkaji peranan kepanitiaan pengadaan barang/jasa yang mempunyai fungsi dan tugas tertuang dalam kontrak perjanjian yang berupa Surat Keputusan (SK) dengan Rektor (Kuasa Pengguna Anggaran) yang disini sebagai pimpinan puncak.

Perbedaan penelitian ini dengan penelitian terdahulu yang dilakukan oleh Jatiningtyas dan Endang (2011) adalah dalam penelitian terdahulu belum memasukkan aspek etika pengadaan dalam penelitiannya. Aspek etika ini dapat memberikan konstribusi atau tidak memberikan kontribusi terhadap indikasi dari fraud pengadaan barang/jasa tergantung dari budaya yang dibangun dalam institusi tersebut. Idealnya, ketika sebuah perguruan tinggi negeri telah memiliki struktur organisasi yang berkaitan dengan proses pengadaan barang/jasa, maka indikasi fraud dalam pengadaan barang/jasa dapat dihindari atau diminimalisir.

Penelitian ini akan mengkaji fraud dalam proses pengadaan barang/jasa di Badan Layanan Umum dengan melihat peranan panitia pada setiap proses pengadaan barang/jasa dari mulai pembuatan spesifikasi, harga, dan pemahaman panitia pada sistem dan prosedur yang ada. Apabila peranan panitia tersebut bekerja secara profesional, tidak memihak dalam pemilihan penyedia barang/jasa, menjunjung tinggi etika, melaksanakan sistem dan prosedur yang ada, sehingga tercipta lingkungan pengadaan yang sehat. maka fraud dalam pengadaan barang/jasa dapat dihindari.

Penelitian ini dilakukan di Universitas Badan Layanan Umum dikarenakan latar belakang kasus adanya praktik korupsi yang terjadi di lima perguruan tinggi negeri sebagaimana dijelaskan di paragraf sebelumnya berkaitan dengan uang
Negara yang bersumber dari rakyat. Selain itu, dalam pelaporan kegiatan yang dilakukan oleh perguruan tinggi ada tanggung jawab kepada direktorat kementerian sehingga peneliti ingin mengkaji pentingnya peranan panitia pengadaan barang/ jasa, kualitas penyedia barang/ jasa,sistem dan prosedur pengadaan barang/jasa, etika pengadaan barang/jasa, lingkungan pengadaan barang/jasa, penilaian risiko dalam pengadaan barang/ jasa sehingga proses pengadaan barang/jasa dapat berjalan dengan baik dan terhindar dari indikasi fraud.

Secara praktis, penelitian ini diharapkan memberikan kontribusi terhadap institusi dengan melihat adanya hubungan antara prinsipal (pemerintah dan rakyat) dan agen (pihak universitas). Diharapkanya dengan temuan penelitian ini, maka peranan panitia, penyedia barang/jasa, prosedur pengadaan barang/jasa, etika pengadaan barang/ jasa, lingkungan pengadaan barang/jasa, penilaian risiko dapat dijalankan secara optimal sehingga faktor-faktor yang dapat mempengaruhi fraud dalam pengadaan barang/jasa di lingkungan Universitas dapat dicegah. Secara teoritis, penelitian ini diharapkan dapat memberikan penjelasan mengenai konflik yang terjadi antara prinsipal pemerintah dan rakyat) dan agen (pihak universitas) khususnya terkait asimetri informasi dalam menjalankan proses pengadaan barang/jasa.

\section{TINJAUAN LITERATUR DAN PERUMUSAN HIPOTESIS}

\section{Teori Keagenan}

Teori keagenan (agency theory) menurut Gudono (2012) dibangun sebagai upaya untuk memahami dan memecahkan masalah yang muncul manakala ada ketidaklengkapan informasi pada saat melakukan kontrak (perikatan). Kontrak yang dimaksud adalah kontrak antara prinsipal (pemberi kerja) atau pimpinan perusahaan dengan agen (penerima perintah). Teori keagenan meramal jika agen memiliki keunggulan informasi dibandingkan prinsipal dan kepentingan agen dan prinsipal berbeda, maka akan terjadi masalah prinsipal-agen agen akan melakukan tindakan yang menguntungkan dirinya namum merugikan prinsipal.

Hubungan prinsipal-agen terjadi apabila tindakan yang dilakukan seseorang memiliki dampak pada orang lain atau ketika seseorang sangat tergantung pada tindakan orang lain. Pengaruh ini diwujudkan dalam kesepakatan-kesepakatan dalam 
struktur institusional pada berbagai tingkatan, seperti norma perilaku dan konsep kontrak. Oleh karena itu konteks permasalahan prinsipal-agen dalam teori keagenan tidak terbatas pada "manajemen vs pemilik" saja, melainkan bisa siapapun selama kedua belah pihak terikat dalam kontrak dan hubungan mereka bisa diposisikan sebagai prinsipal dan agen. Dengan begitu konteks hubungan prinsipal-agen relevan untuk hubunganhubungan antara: pemilik vs manajemen; pimpinan puncak vs bawahan; kreditur vs manajemen; dan pemerintah vs perusahaan (Gudono, 2012)

Berkaitan dengan hal di atas, maka hubungan Pimpinan sebagai Kuasa Pengguna Anggaran dan Unit Layanan Pengadaan (ULP) sebagai unit yang mengadakan proses pengadan barang/jasa terdiri dari pejabat pembuat komitmen, panitia pengadaan, panitia pemeriksa hasil pekerjaan dapat dimasukkan dalam teori keagenan. Teori kegenan ini dapat diterapkan dalam organsasi publik (Lane, 2000 ). Hal ini juga sesuai dengan tempat penelitian pada layanan publik di kalangan Universitas.

Seperti dikemukakan sebelumnya, antara prinsipal dan agen senantiasa terjadi masalah keagenan, hal ini juga terjadi pada kasus fraud yang terjadi pada sektor pengadaan barang/jasa. Pimpinan puncak (Rektor) mempunyai tujuan untuk meningkatkan pelayanan bagi pihak universitas dan berusaha untuk memenuhi kebutuhan tersebut yaitu dengan mempergunakan anggaran dengan sebaikbaiknya, misalnya melalui pengadaan barang/jasa. Namun, tidak semua pihak yang terkait (terutama yang merupakan agen) baik secara langsung maupun tidak langsung mempunyai tujuan dan kepentingan yang sama. Banyak terdapat muatanmuatan kepentingan yang mengganggu tercapainya tujuan utama pengadaan barang/jasa. Peraturan Presiden Republik Indonesia No.54 Tahun 2010 dan Peraturan Presiden Republik Indonesia No 70) Tahun 2012 tentang Pengadaan Barang/Jasa Pemerintah mengemukakan bahwa prinsip umum pengadaan barang/jasa pemerintah antara lain: efisien, efektif, transparan, terbuka dan bersaing, adil/tidak diskriminatif, dan akuntabel.

\section{Beberapa Jenis Fraud dalam Pengadaan Barang/Jasa}

Menurut Tuanakotta (2012) penyebab atau akar masalah dari tindakan fraud adalah fraud by need, fraud by greed and by oppurtinity, $\mathrm{Hal}$ ini mengartikan bahwa ketika fraud ingin dihilangkan maka hilangkanlah faktor dari penyebab fraud itu sendiri. Apabila institusi terbuka dalam penyelesaian fraud maka ketika terjadi indikasi fraud dalam institusi, maka dengan terbuka institusi tersebut memberikan informasi terkait dengan tindakan fraud yang terjadi dalam institusi tersebut. Hal itu akan memberikan efek jera, dan ketika seseorang ingin melakukan tindakan yang sama, maka akan berfikir ulang. Tuanokota (2007) menyatakan bahwa pencegahan fraud dapat dilakukan dengan mengaktifkan pengendalian internal.

Tindakan fraud yang hampr sering dijumpai dalam proses pengadaan barang/jasa adalah ketidaksesuaian antara barang/jasa yang diperjanjikan dalam kontrak dengan kebutuhan instansi dan/ atau masyarakat,baik dilihat dari jenis, kualitas maupun kuantitas barang/jasa. Ketidaksesuaian antara spesifikasi teknis barang/jasa yang telah diselesaikan oleh penyedia barang/jasa dengan spesifikasi teknis yang telah ditetapkan dalam perjanjian/kontrak, ketidaksesuaian antara volume (kuantitas) barang/jasa yang telah diselesaikan oleh penyedia barang dengan jumlah yang seharusnya sesuai perjanjian/kontrak,ketidakwajaran harga barang/jasa yang di sepakati dalam kontrak/perjanjian, keterlambatan penyelesaian pekerjaan oleh rekanan dari jadwal waktu yang telah ditetapkan dalam perjanjian/kontrak (PP No 54 Tahun 2010).

\section{Pengembangan Hipotesis Penelitian}

\section{Kualitas Panitia Pengadaan Barang/Jasa}

Thai (2001) yang didukung oleh penelitian Jatiningtyas dan Endang (2011) mengungkapkan bahwa profesionalisme atau kualitas panitia pengadaan merupakan faktor yang ikut mempengaruhi keberhasilan suatu sistem pengadaan barang/jasa dalam mencapai tujuan yang telah ditetapkan. Akan tetapi hal ini berbeda dengan penelitian Heljapri (2015) yang menyatakan bahwa kualitas penyedia pengadaan barang/jasa tidak berpengaruh terhadap kenderungan fraud. Namun dalam laporan yang dibuat Worldbank (2001), ditemukan bahwa salah satu faktor yang menyebabkan belum berfungsinya sistem pengadaan barang/jasa pemerintah di Indonesia antara lain adalah kurangnya kemampuan sebagian besar staf operasional, anggota panitia lelang dan pihakpihak berwenang yang memberi otorisasi dalam kegiatan pengadaan.

Berdasarkan Tool Kit Anti Korupsi yang disusun oleh Indonesia Procurement Watch (2005), kegiatan pada segmentasi Pembentukan Panitia Lelang perlu diwaspadai sebagai hal yang 
menjadi sebab berkembangnya penyakit Korupsi, Kolusi, dan Nepotisme (KKN), yang memuat berbagai muatan "kepentingan", dalam proses pengadaan barang/jasa pemerintah. Panitia Pengadaan yang terbentuk akan menentukan "hitam" atau "putih"nya suatu proses pengadaan pemerintah mulai dari awal kegiatan pengadaan sampai dengan ditandatanganinya kontrak perjanjian kerja. Segmentasi ini merupakan awal berjangkitnya penyakit-penyakit KKN, diantaranya adalah tersusun atau terbentuknya Panitia Pengadaan yang tidak dilandasi dengan kriteria kemampuan teknis, kredibilitas, serta integritas yang memadai dari anggotanya. Berdasarkan pernyataan di atas, dapat disimpulkan bahwa semakin bagus kualitas panitia pengadaan barang/jasa maka indikasi fraud dalam pengadaan barang/jasa dapat berkurang. Sehingga ditutunkan hipotesis pertama, yaitu:

$\mathrm{H}_{\mathrm{H}}$ : Kualitas panitia pengadaan barang/jasa berhubungan secara negatif terhadap fraud pengadaan barang/jasa.

\section{Kualitas Penyedia Barang/Jasa}

Penelitian Jatiningtyas dan Endang (2011) menyatakan bahwa satu faktor yang mempengaruhi keberhasilan sistem pengadaan barang/jasa adalah profesionalisme atau kualitas penyedia barang/jasa. Akan tetapi hal ini berbeda dengan penelitian Heljapri (2015) yang menyatakan bahwa kualitas penyedia pengadaan barang/jasa tidak berpengaruh terhadap kecenderungan fraud. Menurut landasan hukum Perpres No.54 Tahun 2010 dijelaskan bahwa dalam pasal 19 panitia penyedia barang/jasa wajib memenuhi persyaratan sebagai penyedia barang/jasa, sehingga ketika persyaratan tersebut dipenuhi maka fraud pengadaan barang/ jasa dapat bekurang. Berdasarkan pernyataan diatas semakin bagus kualitas penyedia barang/jasa maka indikasi fraud dalam pengadaan barang/jasa dapat berkurang. Dengan demikian, diturunkan hipotesis kedua, yaitu:

$\mathrm{H}_{2}$ : Kualitas Penyedia Barang/Jasa diharapkan berhubungan secara negatif terhadap terjadinya fraud dalam Pengadaan.

\section{Sistem dan Prosedur Pengadaan Barang/Jasa}

Aspek lain yang ikut menentukan jalannya sistem pengadaan barang/jasa adalah ketentuan dan prosedur pengadaan barang/jasa itu sendiri. Ketentuan dan prosedur pengadaan barang/jasa juga berpengaruh terhadap keberhasilan suatu sistem pengadaan barang/jasa pemerintah dalam mencapai tujuan yang telah ditetapkan (Thai, 2001). Yanavia (2014) menyatakan bahwa sistem dan prosedur pengadaan barang/jasa yang baik dapat mengurangi fraud pengadaan barang/jasa.

Menurut Jourdain dan Balgobin (2003) sebagaimana dikutip Jatiningtyas dan Endang (2011), sistem dan prosedur pengadaan barang / jasa pemerintah yang baik memiliki beberapa karakteristik antara lain: transparency, economy, efficiency and timeliness, fairness and equity. Sistem dan prosedur pengadaan juga harus memiliki mekanisme feedback sehingga memungkinkan upaya perbaikan dan penyempurnaan yang diperlukan. Mekanisme complaint juga perlu diciptakan untuk memperkuat upaya untuk dipatuhinya ketentuan yang digariskan. WorldBank (2001) mengungkapkan bahwa salah satu penyebab belum berfungsinya sistem pengadaan barang/jasa di Indonesia secara baik adalah tidak adanya tindak lanjut terhadap berbagai protes dalam proses pengadaan, dan tidak adanya pemantauan yang sistematik terhadap kepatuhan atas peraturan dan prosedur pengadaan. Berdasarkan pernyataan diatas semakin bagus sistem dan prosedur pengadaan barang/jasa maka indikasi fraud dalam pengadaan barang/jasa dapat berkurang. Sehingga ditutunkan hipotesis ketiga, yaitu:

$\mathrm{H}_{3}$ : Sistem dan Prosedur Pengadaan Barang/Jasa berhubungan secara negatif terhadap fraud pengadaan barang/jasa.

\section{Etika Pengadaan Barang/Jasa}

Etika pengadaan barang/jasa juga merupakan salah satu aspek penting yang perlu diperhatikan untuk terciptanya pengadaan barang/jasa pemerintah yang sehat. Etika pengadaan berkaitan dengan kelaziman dalam praktek dunia usaha yang dianggap akan menciptakan sistem persaingan usaha yang adil. Etika dalam pengadaan barang/jasa akan mencegah penyalahgunaan wewenang atau kolusi untuk kepentingan pribadi atau golongan yang secara langsung atau tidak langsung dapat merugikan negara.

Etika pengadaan barang/jasa yang baik perlu diciptakan untuk mencegah terjadinya kolusi atau korupsi dalam pengadaan barang/jasa pemerintah. Tang et al. (2003) menjelaskan indikator dari perilaku yang menyimpang atau tidak etis dalam organisasi. Perilaku ini terdiri dari perilaku yang menyalahgunakan kedudukan/posisi (abuse position), perilaku yang menyalahgunakan kekuasaan (abuse power), perilaku yang menya- 
lahgunakan sumber daya organisasi (abuse resources), serta perilaku yang tidak berbuat apa-apa (no action).

Jatiningtyas dan Endang (2011) menyatakan bahwa salah satu bentuk perilaku yang etis atau beretika dalam pengadaan barang/ jasa antara lain: para pengguna, penyedia, dan pihak terkait tidak menerima, menawarkan, serta menjanjikan pemberian hadiah atau imbalan berupa apa saja kepada siapa pun yang terkait dengan pengadaan barang/jasa. Sedangkan Yanavia (2014) menyatakan bahwa etika yang baik perlu diciptakan untuk mencegah terjadinya kolusi dan korupsi dalam kegiatan pengadaan barang/jasa. Selain itu merujuk pada konsep yang dikembangkan oleh Associotion of Certified Fraud Examiners (Kassen dan Higson, 2012) menyatakan bahwa salah satu konsep yang relevan untuk menjelaskan isu pencegahan fraud adalah dengan menciptakan keadaan yang memungkinkan pegawai tidak melakukan fraud dengan memiliki konsep pola pikir yang beretika. Berdasarkan pernyataan diatas semakin bagus etika pengadaan barang/jasa maka indikasi fraud dalam pengadaan barang/jasa dapat berkurang. Dengan demikian, diturunkan hipotesis keempat, yaitu:

$\mathrm{H}_{\text {: }}$ Etika pengadaan akan berhubungan secara negatif terhadap fraud pengadaan barang/jasa.

\section{Lingkungan Pengadaan Barang/Jasa}

Sistem dan prosedur pengadaan akan selalu berinteraksi dengan lingkungan dimana sistem tersebut diterapkan. Lingkungan merupakan salah satu faktor yang mempengaruhi kemampuan suatu sistem pengadaan barang/jasa untuk mencapai tujuan yang telah ditetapkan (Thai, 2001). Hal ini berbeda dengan penelitian Heljapri (2015) yang didukung oleh penelitian Astuti (2016) menyatakan bahwa lingkungan pengadaan barang/ jasa tidak memiliki pengaruh terhadap fraud pengadaan barang/jasa. Hal ini berarti ada faktor lain yang menyebabkan kondisi proses pengadaan barang/jasa masih dapat berjalan dengan profesional, yaitu adanya kondisi lingkungan yang jujur dan mendapat insentif sehingga dapat mengurangi tingkat KKN. Namun, Jatiningtyas dan Endang (2011) yang didukung oleh Khi V. Thai (2001) menemukan bahwa salah satu faktor yang mempengaruhi keberhasilan adalah lingkungan pengadaan barang /jasa adalah lingkungan pengadaan. Berdasarkan pernyataan diatas semakin bagus lingkungan pengadaan barang/jasa maka indikasi fraud dalam pengadaan barang/jasa dapat ber- kurang. Dengan demikian, diturunkan hipo-tesis kelima, yaitu:

$\mathrm{H}_{5}$ : Lingkungan pengadaan akan berhubungan secara negatif terhadap fraud pengadaan barang/jasa.

\section{Penilaian Risiko}

Tuanokota (2007) menyatakan bahwa yang dapat dilakukan untuk mencegah fraud adalah dengan menerapkan pengendalian internal yang mana salah satu komponennya adalah penilaian risiko. Penilaian risiko yang dilakukan diha-rapkan mempunyai benteng-benteng yang kokoh dan sulit untuk ditembus oleh mereka yang ingin melakukan tindakan fraud pengadaan barang/jasa. Penilaian risiko pengadaan barang/jasa merupakan pekerjaan yang kompleks dengan maksud bahwa pekerjaan yang dilakukan memerlukan teknologi tinggi, mempunyai risiko tinggi, menggunakan peralatan yang didesain khusus. Hal ini didasari dari penelitian (Fajarina et al., 2011) yang mengatakan bahwa adanya penilaian risiko yang dilakukan oleh pihak pengadaan dengan cara mengidentifikasikan serta melakukan analisis resiko maka akan mengurangi (meminimilasi) terjadinya fraud. Hal ini didukung dengan pernyataan Hermiyetti (2010) menyatakan bahwa penilaian risiko merupakan bagian yang penting dalam hal mencegah fraud agar tercipta kondisi yang baik dalam bekerja. Berdasarkan pernyataan diatas semakin bagus penilaian risiko pengadaan barang/jasa maka indikasi fraud dalam pengadaan barang/jasa dapat berkurang. Sehingga ditutunkan hipotesis keelima, yaitu:

$\mathrm{H}_{6}$ : Penilaian risiko berhubungan secara negatif terhadap fraud pengadaan barang/jasa.

\section{METODE PENELITIAN}

\section{Model Penelitian}

Berdasarkan perumusan hipotesis, dirumuskan model penelitian yang disajikan di Gambar 1 .

\section{Definisi Operasional Variabel \\ Variabel Dependen (Fraud Pengadaan Barang/Jasa)}

Fraud dalam penelitian ini adalah serangkaian ketidakberesan (irregularities) mengenai: 
perbuatan-perbuatan melawan hukum (illegal act), yang dilakukan dengan sengaja untuk tujuan tertentu (misalnya menipu memberikan gambaran yang keliru (mislead) terhadap pihak lain), yang dilakukan oleh orang-orang dari dalam ataupun dari luar organisasi, untuk mendapatkan keuntungan baik pribadi maupun kelompok, dan secara langsung atau tidak langsung merugikan pihak lain (Tuanakotta, 2012).

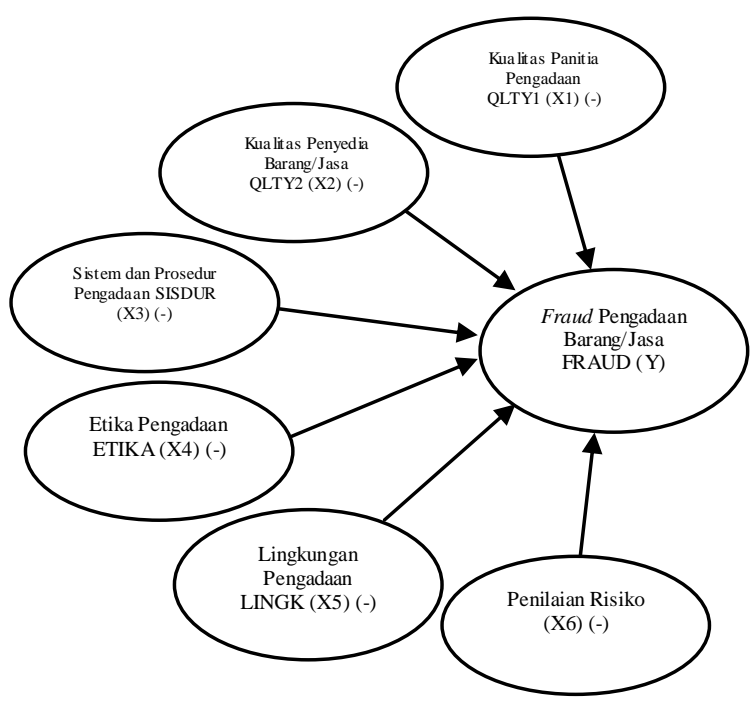

Gambar 1. Model Penelitian

\section{Variabel Independen}

Kualitas Panitia Pengadaan Barang/Jasa

Kualitas yang dimaksudkan dalam penelitian ini adalah suatu kondisi dinamis yang terjadi ketika panitia mempunyai profesionalisme dalam melakukan proses pengadaan barang/jasa. Panitia yang dimaksud terdiri dari: pengguna anggaran (PA)/kuasa pengguna anggaran (KPA), pejabat pembuat komitmen (PPK), pejabat pengadaan/ unit layanan pengadaan (ULP), dan panitia/ pejabat penerima hasil pekerjaan. Secara operasional, kualitas panitia pengadaan barang/jasa di sini mengacu pada apakah panitia pengadaan barang/ jasa tersebut secara fungsional dapat melaksanakan tugas dan fungsinya sesuai dengan prinsip-prinsip dasar pengadaan yang terdiri dari integritas, kompetensi, objektivitas dan independensi (Jatiningtyas dan Endang, 2011).

Kualitas Penyedia Barang/Jasa

Penyedia barang/jasa adalah badan usaha atau orang perseorangan yang menyediakan suatu
Barang/Pekerjaan, Konstruksi/Jasa, Konsultansi/ Jasa Lainnya (Jatiningtyas dan Endang, 2011). Jadi yang dimaksud dengan kualitas penyedia barang/jasa di sini adalah apakah badan usaha atau orang perseorangan yang menyediakan Barang/Pekerjaan Konstruksi/Jasa Konsultansi/ Jasa Lainnya telah memenuhi kriteria yang telah dipersyaratkan dalam peraturan yang telah ditetapkan

Sistem dan Prosedur Pengadaan Barang/Jasa

Ketentuan dan prosedur pengadaan barang/ jasa juga berpengaruh terhadap keberhasilan suatu sistem pengadaan barang/jasa pemerintah dalam mencapai tujuan yang telah ditetapkan (Thai, 2001). Menurut Jourdain dan Balgobin (2003) sebagaimana dikutip Jatiningtyas dan Endang (2011) sistem dan prosedur pengadaan barang/ jasa pemerintah yang baik memiliki beberapa karakteristik antara lain :Tranparency, Economy, Efficiency and timeliness, Fairness and equity. Jadi yang dimaksud dengan sistem dan prosedur pengadaan barang/jasa adalah mekanisme yang dilakukan sesuai dengan tujuan pengadaan barang/jasa.

\section{Etika Pengadaan Barang/Jasa}

Pengertian Etika (Etimologi), berasal dari bahasa Yunani adalah Ethos, yang berarti watak kesusilaan atau adat kebiasaan (Agoes dan Ardana, 2009). Etika biasanya berkaitan erat dengan perkataan moral yang merupakan istilah dari bahasa Latin, yaitu Mos dan dalam bentuk jamaknya Mores, yang berarti juga adat kebiasaan atau cara hidup seseorang dengan melakukan perbuatan yang baik (kesusilaan), dan menghindari hal-hal tindakan yang buruk (Agoes dan Ardana, 2009). Etika yang dimaksudkan di dalam penelitian ini adalah pengkajian sistem nilai-nilai yang berlaku terutama yang diberlakukan pada proses pengadaan barang/jasa.

\section{Lingkungan Pengadaan Barang/Jasa}

Lingkungan yang dimaksud di sini adalah lingkungan kerja di mana proses pengadaan barang/jasa dilaksanakan. Hal ini dilandasi pendapat Thai (2001) yang mengungkapkan bahwa salah satu faktor yang mempengaruhi keberhasilan sistem pengadaan barang/jasa adalah lingkungan pengadaan, baik secara internal maupun eksternal. 
Penilaian Risiko

Penilaian Risiko dalam kegiatan yang dilakukan oleh universitas adalah mekanisme terkait pemberian penilaian atas risiko yang dihadapi unit organisasi baik dari luar maupun dari dalam. Identifikasi risiko dilaksanakan dengan metodologi yang sesuai dengan tujuan Instansi dan tujuan pada tingkatan kegiatan secara menyeluruh; menggunakan mekanisme yang memadai untuk mengenali risiko dari faktor eksternal dan faktor internal, dan menilai faktor lain yang dapat meningkatkan risiko (Fajarina et al., 2012).

\section{Populasi dan Sampel}

Populasi dalam penelitian ini adalah panitia pengadaan barang/jasa di perguruan tinggi yang menjadi lokasi penelitian, dengan rincian: pejabat pembuat komitmen yang berjumlah 3 orang, panitia pengadaan berjumlah 22 orang, dan panitia/pejabat penerima hasil pekerjaan berjumlah 25 orang yang berada di Direktorat Pengelolaan dan Pemeliharaan Aset Universitas Berbasis menuju Badan Layanan Umum di Wilayah Kota Yogyakarta. Sampel adalah bagian dari populasi. Penelitian ini menggunakan total sampling (sensus), yang maksudnya responden yang dijadikan dalam penelitian ini yakni seluruh pihak yang terlibat dalam proses pengadaan barang/jasa.

\section{Jenis dan Sumber Data}

Rancangan penelitian yang akan digunakan adalah dilakukan dengan metode survei dengan menyebarkan kuesioner kepada responden yang bertujuan untuk mengumpulkan informasi sehingga diperoleh data-data yang valid. Data yang digunakan adalah data primer yang diperoleh dari hasil survei kepada pejabat pembuat komitmen, panitia pengadaan, panitia pemeriksa hasil pekerjaan. Pengumpulan data dilakukan dengan menggunakan survei melalui pengiriman kuesioner. Kuesioner dikirimkan langsung oleh peneliti ke Direktorat Pengelolaan dan Pemeliharaan Aset Universitas.

\section{Instrumen dan Skala Pengukuran data Penelitian}

Dalam penelitian kuantitatif, peneliti akan menggunakan instrumen untuk mengumpulkan data. Instrumen ini digunakan untuk mengukur nilai variabel yang diteliti. Dengan demikian instrumen yang akan digunakan untuk penelitian ini adalah kuesioner yang berisi item petanyaan yang merujuk pada indikator-indikator dari konstruk variabel-variabel penelitian. Karena instrumen penelitian akan digunakan untuk melakukan pengukuran dengan tujuan menghasilkan data kuantitatif yang akurat, maka setiap instrumen harus mempunyai skala.

Dalam penelitian ini peneliti menggunakan skala likert. Skala likert digunakan untuk mengukur sikap, pendapat dan persepsi seseorang atau sekelompok orang tentang fenomena sosial (Sugiyono, 2008). Dengan skala likert, maka variabel yang akan diukur dijabarkan menjadi indikator variabel. Kemudian indikator tersebut dijadikan sebagai titik tolak untuk menyusun itemitem instrumen yang dapat berupa pernyataan atau pertanyaan. Instrumen dalam penelitian ini disajikan pada Tabel 1.Dari pertanyaan yang ada pada Tabel 1, jawaban responden akan dinilai dengan aturan; SS (Sangat Setuju), diberi skor 5; S (Setuju) diberi skor4; R (Ragu-Ragu) diberi skor 3; TS (Tidak setuju) diberi skor 2; STS (Sangat Tidak Setuju) diberi skor 1.

\section{HASIL DAN PEMBAHASAN}

Pembahasan pada bab ini meliputi hasil penelitian untuk menganalisa faktor-faktor yang mempengaruhi fraud pengadaan barang/jasa pada Direktorat Pengelolaan dan Pemeliharaan Aset yang dibagi dalam: (1) kualitas panitia pengadaan barang/jasa; (2) kualitas penyedia barang/ jasa; (3) sistem dan prosedur pengadaan barang/ jasa,(4) etika pengadaan barang/jasa; (5) lingkungan pengadaan; (6) penilaian risiko; dan (7) fraud pengadaan barang/jasa. Hasil penelitian meliputi, uji kualitas data, uji hipotesis, dan pembahasan uji hipotesis.

\section{Uji Kualitas Data}

\section{Uji Validitas dan Realibilitas}

Hasil uji validitas menunjukkan bahwa koefisien korelasi pearson moment untuk setiap item butir pernyataan dengan skor total variabel fraud pengadaan barang/jasa $(\mathrm{Y})$, kualitas panitia pengadaan barang/jasa (QLTY1), kualitas penyedia barang/jasa (QLTY2), sistem dan prosedur pengadaan barang/jasa (SISDUR), etika pengadaan barang/jasa (ETIKA), lingkungan Penga- 
Tabel 1. Instrumen Penelitian

\begin{tabular}{|c|c|c|c|}
\hline No. & Variabel & Indikator & Pertanyaan \\
\hline \multicolumn{4}{|c|}{ Variabel Independen } \\
\hline \multirow[t]{6}{*}{1} & $\begin{array}{l}\text { Kualitas Panitia } \\
\text { Pengadaan }\end{array}$ & Integritas & $\begin{array}{l}\text { 1. Sistem dalam pengadaan barang/jasa telah berjalan } \\
\text { sesuai dengan visi dan misi lembaga }\end{array}$ \\
\hline & Barang/Jasa & & $\begin{array}{l}\text { 2. Dilakukan tindakan ketika ada pihak-pihak yang } \\
\text { berusaha melakukan intervensi atau memaksakan } \\
\text { kehendak untuk memenangkan salah satu calon } \\
\text { peserta lelang (pengadaan barang/jasa) }\end{array}$ \\
\hline & & & $\begin{array}{l}\text { 3. Pencapaian ketaatan terhadap kebijakan dalam } \\
\text { penandatangan pakta integritas masih sangat minim }\end{array}$ \\
\hline & & Kompetensi & $\begin{array}{l}\text { 1. Mempunyai pemahaman dan pengetahuan yang } \\
\text { cukup mengenai sistem dan prosedur pengadaan } \\
\text { barang/jasa yang akan dilaksanakan }\end{array}$ \\
\hline & & & $\begin{array}{l}\text { 2. Panitia lelang telah memiliki sertifikat keahlian pe- } \\
\text { ngadaan barang/jasa atau pernah mengikuti pela- } \\
\text { tihan pengadaan barang/jasa }\end{array}$ \\
\hline & & $\begin{array}{l}\text { Objektivitas dan } \\
\text { Independensi }\end{array}$ & $\begin{array}{l}\text { 1. Dalam penyusunan panitia berdasarkan pada kri- } \\
\text { teria kemampuan teknis, mempunyai kredibilitas } \\
\text { dan integritas sehingga tidak memihak kepada } \\
\text { salah satu atau sekelompok peserta dalam proses } \\
\text { pengadaan barang/jasa }\end{array}$ \\
\hline \multirow[t]{3}{*}{2.} & $\begin{array}{l}\text { Kualitas Penyedia } \\
\text { Barang/Jasa }\end{array}$ & $\begin{array}{l}\text { Landasan } \\
\text { Hukum }\end{array}$ & $\begin{array}{l}\text { 1. Penyedia barang/jasa memenuhi ketentuan perun- } \\
\text { dang-undangan dalam menjalankan kegiatan/usaha }\end{array}$ \\
\hline & & & $\begin{array}{l}\text { 2. Penyedia barang/jasa memiliki keahlian, penga- } \\
\text { laman, kemampuan teknis dan manajerial untuk } \\
\text { menyediakan barang/jasa }\end{array}$ \\
\hline & & & $\begin{array}{l}\text { 3. Pencapaian ketaatan penyedia barang/jasa terha- } \\
\text { dap kebijakan dalam penandatangan pakta integ- } \\
\text { ritas masih sangat minim }\end{array}$ \\
\hline \multirow[t]{7}{*}{3.} & $\begin{array}{l}\text { Sistem dan } \\
\text { Prosedur }\end{array}$ & Transparansi & $\begin{array}{l}\text { 1. Dilakukan sosialisasi terhadap rencana kegiatan pe- } \\
\text { ngadaan barang/jasa }\end{array}$ \\
\hline & $\begin{array}{l}\text { pengadaan } \\
\text { barang/jasa }\end{array}$ & & $\begin{array}{l}\text { 2. Dalam pengumuman pengadaan barang/jasa dila- } \\
\text { kukan melalui media cetak /media elektronik/ } \\
\text { internet }\end{array}$ \\
\hline & & & $\begin{array}{l}\text { 3. Semua tahapan dalam proses pengadaan barang/ } \\
\text { jasa diketahui oleh publik secara jelas dan terbuka }\end{array}$ \\
\hline & & Ekonomis & $\begin{array}{l}\text { 1. Penentuan Harga Perkiraan Sendiri (HPS) dila- } \\
\text { kukan dalam setiap proses pengadaan barang/jasa } \\
\text { 2. Penetapan pemenang adalah penawar dengan } \\
\text { harga terendah }\end{array}$ \\
\hline & & $\begin{array}{l}\text { Efisiensi dan } \\
\text { Tepat Waktu }\end{array}$ & $\begin{array}{l}\text { 1. Pengadaan barang/jasa dilakukan tepat waktu dan } \\
\text { sesuai dengan kebutuhan }\end{array}$ \\
\hline & & $\begin{array}{l}\text { Keadilan dan } \\
\text { Ekuitas }\end{array}$ & $\begin{array}{l}\text { 1. Dokumen lelang diperuntukkan bagi kelompok } \\
\text { penyedia barang /jasa tertentu saja }\end{array}$ \\
\hline & & & $\begin{array}{l}\text { 2. Penyedia barang/jasa dipilih berdasarkan kuali- } \\
\text { fikasi dan kelayakan penawaran }\end{array}$ \\
\hline \multirow[t]{3}{*}{4.} & $\begin{array}{l}\text { Etika Pengadaan } \\
\text { Barang/Jasa }\end{array}$ & & $\begin{array}{l}\text { 1. Dalam proses pengadaan barang/jasa adalah wajar } \\
\text { bila meminta hadiah kepada peserta pengadaan } \\
\text { agar lolos dalam proses pengadaan barang/jasa }\end{array}$ \\
\hline & & & $\begin{array}{l}\text { 2. Dalam proses pengadaan barang/jasa adalah wajar } \\
\text { bila mengijinkan peserta pengadaan bertindak } \\
\text { sebagai calo }\end{array}$ \\
\hline & & & 3. Dalam proses pengadaan barang/jasa adalah tidak \\
\hline
\end{tabular}




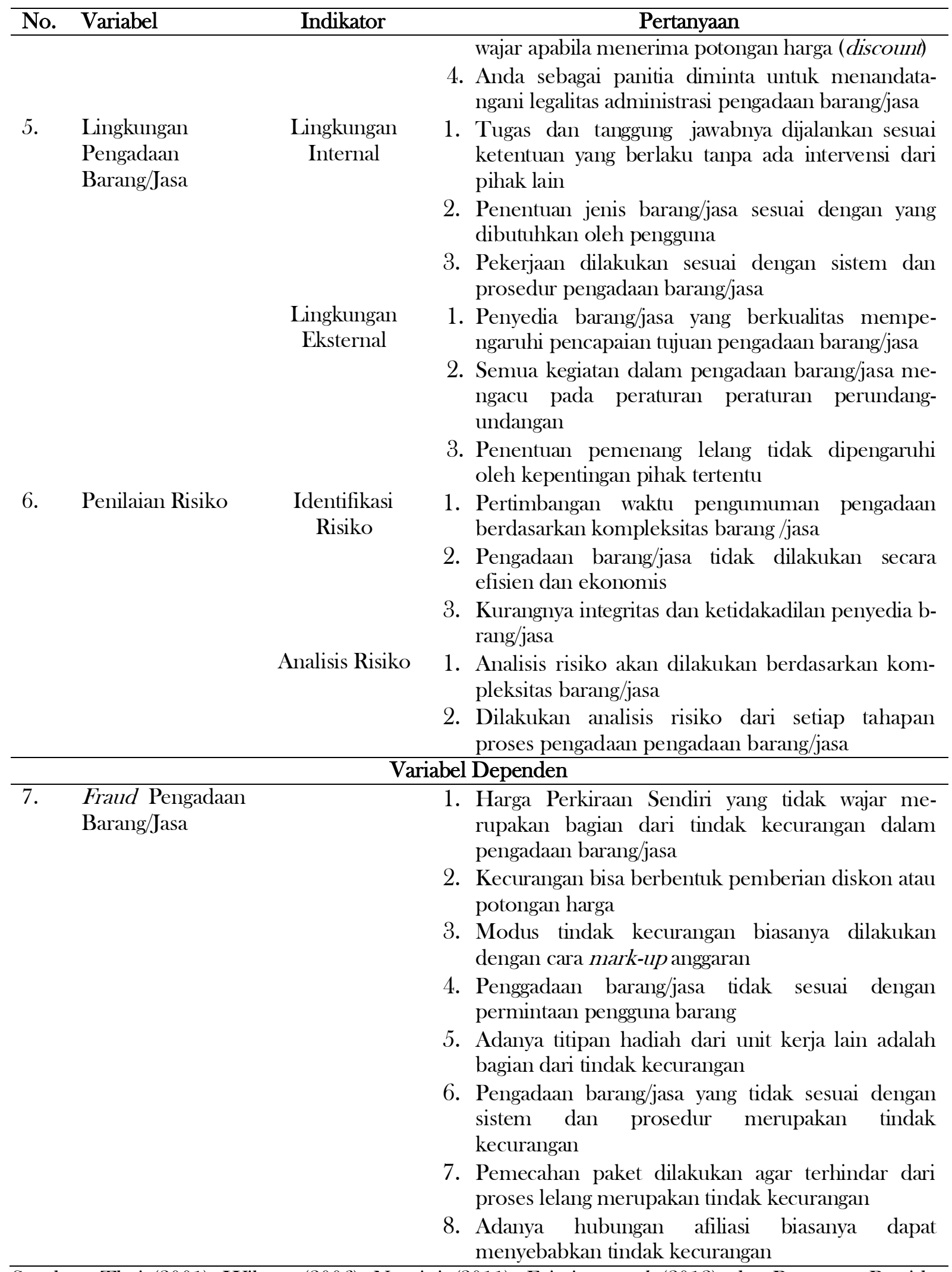

Sumber: Thai (2001), Wilopo (2006), Nuraini (2011), Fajarina et al. (2012) ,dan Peraturan Presiden Republik Indonesia No.54 Tahun 2010 Tentang Pengadaan Barang/Jasa Pemerintah. 
daan barang/jasa (Lingk.Peng) dan Penilaian Risiko (PEN.RISK) signifikan pada tingkat signifikansi 0,01 . Dengan demikian dapat diinterpretasikan bahwa setiap item indikator instrumen untuk fraud pengadaan barang/jasa tersebut valid.

Hasil perhitungan uji realibilitas menunjukkan bahwa nilai cronbrach alpha $(\alpha)$ untuk masing-masing variabel adalah lebih besar dari 0,50 dengan demikian dapat disimpulkan bahwa item-item instrumen untuk masing-masing variabel adalah reliabel (Ghozali, 2011).

\section{Uji Asumsi Klasik}

Sebelum dilakukan pengujian hipotesis menggunakan regresi linier berganda, ada beberapa uji asumsi klasik yang harus dipenuhi agar kesimpulan dari regresi tersebut tidak bias, yaitu uji normalitas, uji multikolinieritas, dan uji heteroskodesitas. Hasil dari uji asumsi klasik normalitas, multikolinieritas, dan heteroskedastisitas yang telah dilakukan dengan model regresi berganda yang digunakan dalam penelitian ini menunjukkan bahwa model regresi berganda tersebut memenuhi syarat normalitas yang ditandai dengan nilai KS sebesar 0,676. Nilai ini tidak signifikan pada 0,05 (karena nilai $P=0,750$, lebih besar dari $0,05)$. Hal tersebut memberikan gambaran bahwa sebaran data tidak menunjukkan penyimpangan dari kurva normalnya, yang berarti bahwa sebaran data telah memenuhi asumsi normalitas, selain itu terkait dengan multikolinieritas menunjukkan angka tolerance dari variabel independen kompetensi dan independensi mempunyai nilai tolerance lebih dari 0,10 yang berarti bahwa tidak ada korelasi antar variabel indpenden yang nilainya lebih dari 95\%. Sementara itu, hasil perhitungan nilai Variance Inflantion Factor (VIF) juga menunjukkan hal yang sama.

Tidak ada satupun variabel independen yang memiliki nilai VIF lebih dari 10. Dengan demikian dapat disimpulkan dalam model regresi tidak terjadi multikolinieritas antar variabel inde- penden tersebut. Sedangkan heteroskedastisitas grafik scatterplot tampak bahwa sebaran data tidak membentuk pola yang jelas, titik-titik data menyebar di atas dan di bawah angka 0 sumbu Y. Hal ini mengindikasikan bahwa tidak terjadi heteroskedastisitas dalam model regresi. Dengan demikian, maka model regresi berganda layak untuk digunakan.

\section{Hasil Analisis Regresi Berganda `}

Berdasarkan tampilan output besarnya adjustted $\mathbf{R}^{2}$ (koefisien determinasi yang telah disesuaikan) adalah 0,341. Nilai ini menunjukkan bahwa $31,4 \%$ variasi fraud pengadaan barang/jasa dijelaskan oleh variasi dari keenam variabel independen, yaitu; kualitas panitia pengadaan barang/ jasa, kualitas penyedia barang/jasa, sistem dan prosedur pengadaan barang/jasa, etika pengadaan barang/jasa, lingkungan pengadaan barang/jasa dan penilaian risiko. Sedangkan sisanya $68,6 \%$ dijelaskan oleh variabel lain di luar model.

Hipotesis pertama menyatakan bahwa kualitas panitia pengadaan berpengaruh signifikan terhadap fraud pengadaan. Hasil pengujian hipotesis ini sejalan dengan pendapat Thai (2001) mengungkapkan bahwa profesionalisme atau kualitas panitia pengadaan merupakan faktor yang ikut mempengaruhi keberhasilan suatu sistem pengadaan barang/jasa dalam mencapai tujuan yang telah ditetapkan. Profesional dalam penelitian ini diproksikan dalam integritas panitia, kompetensi, obyektifitas dan independensi. Sehingga, dapat dilihat bahwa kemampuan dan profesionalisme personil panitia pengadaan dapat mengurangi seorang panitia untuk melakukan tindakan fraud dalam proses pengadaan barang/ jasa. Hasil tersebut dapat dipahami bahwa untuk meningkatkan kualitas panitia pengadaan, seorang panitia sangat bergantung pada tingkat profesionalisme dan kemampuannya. Jika panitia pengadaan memiliki profesionalisme dan kemampuan

Tabel 2. Ringkasan Pengujian Hiptesis dengan Uji t

\begin{tabular}{|c|c|c|c|c|}
\hline Model Hubungan & $\begin{array}{l}\text { Unstandardized } \\
\text { Coefficients } \\
\text { B Std. Error }\end{array}$ & $\begin{array}{c}\text { Beta } \\
\text { Standardized } \\
\text { Coefficient }\end{array}$ & Sig. & Simpulan \\
\hline QLTY1 &,- 608 &,- 590 &, $007^{*}$ & Terdukung \\
\hline QLTY2 &,- 731 &,- 311 &, $070^{* *}$ & Terdukung \\
\hline SISDUR &,- 845 &,- 815 &, $001^{*}$ & Terdukung \\
\hline ETIKA & ,028 & ,031 & 857 & Tidak Terdukung \\
\hline LINGK & ,078 & ,097 & 654 & Tidak Terdukung \\
\hline PENRISK &,- 417 &,- 367 &, $054^{* *}$ & Terdukung \\
\hline
\end{tabular}


yang baik maka panitia tidak akan dengan mudah tergoda untuk melakukan fraud pada kegiatan pengadaan barang/jasa. Sebaliknya, jika profesionalisme dan kemampuan panitia rendah, maka dalam melaksanakan tugasnya, panitia akan dengan mudah tergoda untuk melakukan fraud pada kegiatan pengadaan barang/jasa. Oleh kerena itu, dapat disimpulkan ketika seorang panitia bertindak profesional, maka konflik kepentingan diantara prinsipal dan agen dapat terhindari karena panitia bekerja berdasarkan standar operasional tanpa ada keinginan untuk berbuat kecurangan.

Hasil pengujian hipotesis kedua ditemukan bahwa kualitas penyedia barang/jasa berpengaruh negatif terhadap fraud pengadaan baran/jasa. Hasil ini sejalan dengan pendapat Jatiningtyas dan Endang (2011) yang menjelaskan bahwa kualitas panitia merupakan salah satu elemen penting dalam suatu sistem pengadaan barang/jasa. Jika suatu pengadaan barang/jasa tidak diikuti dengan kualitas penyedia yang baik, maka akan terdapat banyak kesalahpahaman/misunderstanding diantara panitia dan penyedia barang/jasa yang nantinya akan merugikan kedua belah pihak. Profesionalisme atau kualitas penyedia barang/jasa merupakan faktor yang ikut mempengaruhi keberhasilan suatu sistem pengadaan barang/jasa dalam mencapai tujuan yang telah ditetapkan.

Dari uji hipotesis ketiga disimpulkan sistem prosedur pengadaan barang/jasa juga berpengaruh negatif terhadap fraud pengadaan barang/ jasa. Hasil ini sejalan dengan pendapat Thai (2001) yang mengungkapkan bahwa ketentuan dan prosedur pengadaan barang/jasa juga berpengaruh terhadap keberhasilan suatu sistem pengadaan barang/jasa pemerintah dalam mencapai tujuan yang telah ditetapkan. Selain itu, Landasan hukum dari sistem dan prosedur yang berlaku harus cukup kuat, sehingga upaya penegakan ketentuan yang diaturnya dapat dilakukan secara efektif (World Bank, 2001).

Salah satu yang menarik dari hasil penelitian ini adalah tidak terdukungnya hipotesis keempat, atau aspek etika terhadap fraud pengadaan barang/jasa. Hasil ini justru sejalan dengan pendapat Buckley et al. (1998) sebagaimana dikutip Wilopo (2006) yang menjelaskan bahwa perilaku tidak etis (tidak beretika) merupakan sesuatu yang sulit untuk dimengerti, yang jawabannya tergantung pada interaksi yang kompleks antara situasi serta karateristik pribadi pelakunya. Tidak terdukungnya hipotesis keempat ini diduga karena ketidaksadaran panitia akan aspek etis dalam melakukan tindakan fraud. Karenanya, adanya kode etik terkait dengan etika penting untuk diadakan, agar kesadaran akan aspek etika ini muncul pada praktik pengadaan barang/jasa. Kemungkinan lain adalah kuatnya pengaruh kualitas panitia dan penyedia barang/jasa, serta sistem dan prosedur sebagaimana hasil temuan penelitian ini (terdukungnya hipotesis satu, dua, dan tiga). Dengan demikian, ada kemungkinan meskipun etika panitia rendah namun ketika kepanitiannya berkualitas dan sistem prosedurnya juga baik, maka fraud dapat dicegah.

Hipotesis kelima penelitian ini juga tidak terdukung. Hasil ini sejalan dengan penelitian Astuti (2016) yang menjelaskan tidak berpengaruhnya lingkungan pengadan barang/jasa terhadap fraud pengadan barang/jasa diduga karena lingkungan pengadaan barang/jasa yang ada belum mempunyai pengaruh dalam pencapaian tujuan. Hal ini bisa jadi dikarenakan tidak adanya supervisi dalam setiap tahapan proes pengadaan atau tidak adanya pre-audit (menetapkan rencana awal dari proses pengadaan). Supervisi hanya dilakukan setelah pekerjaan selesai atau hanya dilakukan post-audit (evaluasi dilakukan setelah proses pengadaan selesai) saja. Kondisi ini menjadikan lingkungan pengadaan barang/jasa tidak terkendali secara ideal, dan akhirnya apa yang dikatakan Thai (2001) bahwa lingkungan pengadaan dipengaruhi oleh market environment dan legal environment, belum mempunyai pengaruh terhadap fraud pengadaan barang/jasa.

Selanjutnya, hasil uji hipotesis keenam menemukan bahwa penilaian risiko yang dilakukan memiliki pengaruh terhadap fraud pengadaan barang/jasa. Pengujian hipotesis ini sejalan dengan hasil penelitian (Fajarina et al., 2012) yang mengungkapkan bahwa apabila penilaian risiko tidak diterapkan maka akan meningkatkan tindakan fraud. Sebaliknya, adanya penilaian risiko akan dapat memitigasi adanya fraud. Oleh karenanya, penilaian risiko dalam kegiatan pengadaan barang/jasa sangat penting dilakukan oleh pimpinan organisasi. Penilaian risiko oleh pimpinan dilakukan dengan cara mengidentifikasi serta melakukan analisis risiko. Sevagai contoh, dalam mempertimbangkan waktu pengumuman pengadaan barang/jasa, harus disesuaikan dengan kompleksitas dari barang/jasa tersebut. Jangan sampai ketika proses pengadaan barang/jasa tersebut mempunyai kompleksitas yang tinggi, namun waktu pengumumannya tidak relevan, sehingga risiko yang diterima menjadi lebih besar daripada ketika waktu pengumuman direnca- 
nakan sesuai dengan kompleksitas pengadaan barang/jasa tersebut. Kompleksitas yang dimaksud disini adalah pengadaan yang mempunyai nilai lebih besar tentunya kompleksitsnya berbeda dengan pengadaan barang/jasa yang nilainya lebih kecil, sehingga dari mekanisme waktu pengumuman menjadi berbeda tergantung dari nilai pengadaan tersebut. Oleh karena itu, semakin baik penilaian risiko yang diterapkan maka akan meminimalisasi terjadinya fraud.

\section{SIMPULAN}

Hasil penelitian ini menemukan bahwa kualitas panitia pengadaan, kualitas penyedia barang/jasa, sistem dan prosedur pengadaan, etika pengadaan, lingkungan pengadaan dan penilaian risiko berpengaruh terhadap fraud pengadaan barang/jasa, pada konteks penelitian ini, di perguruan tinggi negeri. Temuan ini mengindikasikan bahwa semakin baik tingkat kualitas panitia pengadaan, kualitas penyedia barang/jasa, sistem dan prosedur pengadaan dan penilaian risiko, maka fraud pengadaan barang/jasa berkurang. Etika pengadaan dan lingkungan pengadaan ternyata ditemukan tidak berpengaruh secara signifikan terhadap fraud pengadaan barang/jasa. Hal ini bisa jadi karena perbuatan tidak etis itu sulit untuk dimengerti dan diprediksi. Selain etika, ligkungan pengadaan barang/jasa juga tidak memiliki pengaruh terhadap adanya indikasi fraud.

Implikasi dari temuan penelitian ini adalah pentingnya menjaga kualitas panitia dan penyedia pengadaan barang/jasa, ketaatan pada sistem dan prosedur pengadaan, serta dilakukannya penilaian risiko dalam melakukan pengadaan barang/jasa. Hal ini bertujuan guna meminimalisir fraud pada pengadaan barang/jasa.

Penelitian ini mempunyai beberapa keterbatasan yang selanjutnya bisa menjadi masukkan bagi peneliti selanjutnya yang tertarik untuk meneliti terkait tema sejenis. Pertama, lokasi penelitian hanya satu Perguruan Tinggi Negeri saja. Kare-nanya, dilihat dari segi generalisasi masih lemah. Oleh karena itu, peneliti selanjutnya perlu untuk menambah objek penelitian menjadi lebih dari satu Perguruan Tinggi, baik negeri maupun swasta agar hasil penelitian bisa digeneralisasi lebih luas. Kedua, penelitian ini menggunakan model kuesioner sehingga dimungkinkan terjadi bias ketika responden menjawab kuesioner. Oleh karenanya penelitian mendatang sebaiknya me- ngembangkan model penelitian dengan metode lain, seperti eksperimen atau investigatif. Terakhir, penelitian ini tdak melibatkan responden dari penyedia barang/jasa. Sehingga, untuk penelitian mendatang disarankan sebaiknya melakukan sebuah penelitian dengan melibatkan pihak penyedia barang/jasa agar dapat menemukan temuan dari persepsi yang berbeda.

\section{DAFTAR PUSTAKA}

Agoes, S., dan I. C. Ardana. 2009. Etika bisnis dan profesi: tantangan membangun manusia seutuhnya. Jakarta: Penerbit Salemba.

Astuti, H. 2016. Analisis Faktor-Faktor Yang Mempengaruhi Fraud Pengadaan Barang/ Jasa Di Lingkungan Instansi Pemerintah Provinsi Kepulauan Riau. Skripsi, Universitas Maritim Raja Ali Haji.

Detiknews, 2013, Tiga Dosen UNM Didakwa Kasus Korupsi Pengadaan Alat Lab MIPA. http//www.detiknews.com

Fajarina, W., Darwanis, dan U. A. Bakar, 2012, Pengaruh Lingkungan Pengendalian, Penilaian Risiko, Kegiatan Pengendalian, Informasi dan Komunikasi, Serta Pemantauan Terhadap Pencegahan Fraud Pengadaan Barang/Jasa Pada SKPD di Pemerintah Aceh, Jurnal Akuntansi Pascasarjana Universitas Syiah Kuala, 2 (2), 245-253.

Gudono. 2012. Analisis Data Multivariat. Yogyakarta: Penerbit BPFE Yogyakarta.

Ghozali, I. 2011. Aplikasi Analisis Multivariate Dengan Program IBM SPSS.19., Semarang: Badan Penerbit Univer-sitas Diponegoro.

Heljapri. 2015. Perbedaan Persepsi Antara Pihak Internal Instansi Pemerintah Dengan Auditor Bpkp Tentang Aspek Penyebab Fraud Pengadaan Barang/Jasa Pada Lingkungan Pemerintah Propinsi SumateraBarat (Studi Empiris pada SKPD Kabupaten/Kota dan auditor BPKP Sumatra Barat). Skripsi, Universitas Negeri Padang.

Hermivetti. 2011. Pengaruh Penerapan Pengendalian Internal Terhadap Pencegahan Fraud Pengadaan Barang. Skrispsi, STEKPI Jakarta.

Jatiningtyas, N. dan K. Endang. 2011. Analisis Faktor-Faktor Yang Mempengurahi Fraud Pengadaan Barang/Jasa Pada Lingkungan Instansi Pemerintah Di Wilayah Semarang. Tesis, Universitas Diponegoro. 
Laporan Tahunan KPK”, 2013, www:http//:www.kpk.go.id

Peraturan Presiden Republik Indonesia N0.54 Tahun 2010 tentang Pengadaan Barang/Jasa Pemerintah

Rahardja, A. 2010. Efisiensi Dalam Pengadaan Barang/Jasa Pemerintah: Perspektif Pencegahan Korupsi, One Day Workshop Procurement Efficiency, Perusahaan Listrik Negara Komisi Pemberantasan Korupsi

Razzaque, M. A. dan T. P. Hwee. 2002. Ethics and Purchasing Dilemma; A Singaporean View, Journal of Business Ethics, 35 (4), 307-326.

Sugiyono. 2008. Metode Penelitian Kuantitatif dan Kualitatif dan R\&D. Bandung: Penerbit Alfabeta.

Thai, K. V. 2001. Public Procurement Reexamined. Journal of Public Procurement, 1 (1), 9-50.

Tuanakota, T. M., 2012 , Akuntansi Forensik \& Audit Investigasi. Jakarta: Penerbit Salemba Empat.

Yanavia, L. N. 2014, Analisis Faktor-Faktor Yang Mendorong Terjadinya Fraud Pengadaan Barang/Jasa Pada Instansi Pemerintah Di Propinsi Sumatera Barat, Skripsi, Universitas Negeri Padang.

Wilopo, 2006, Analisis faktor-faktor yang berpengaruh Terhadap kecenderungan terjadinya kecurangan Akuntansi : Studi pada Perusahaan BUMN dan Publik di Indonesia, The Indonesian Journal of Accounting Research, 9 (3), 451-465.

World Bank. 2001. Indonesia Country Procurement Assessment Report :

Reforming the Public Procurement System, website: http//

www.siteresources.worldbank.org. 